\title{
Iniciação à periferia: leitura dramática de Dalcídio Jurandir
}

\section{Initiation to the periphery: a dramatic reading of Dalcídio Jurandir}

Willi Bolle - Professor de literatura na Universidade de São Paulo e pesquisador do CNPq. E-mail: willibolle@yahoo.com

\section{Resumo}

As condições de vida na periferia das grandes cidades do nosso "Planeta Favela" são um desafio que afeta a todos. Um exemplo paradigmático é a obra do escritor paraense Dalcídio Jurandir (1909-1979), que escolheu a periferia de Belém como cenário para a metade dos dez romances que compõem o seu "Ciclo do Extremo Norte". Aqui focalizamos o primeiro desses romances, Passagem dos Inocentes (1963), a partir de uma adaptação cênica que foi feita com professores e alunos da periferia. Trata-se da iniciação de um jovem que migrou do interior da Amazônia para a grande cidade, da rotina do cotidiano da dona de casa que o hospeda ali num barraco, e dos desejos de evasão dela, aos quais o autor contrapõe uma manifestação política que chama a atenção para os problemas crônicos dos bairros pobres. A importância deste romance no conjunto do Ciclo Amazônico de Dalcídio devese, sobretudo, ao relevo dado à fala dos personagens. Nesse sentido, o método da oficina teatral aqui descrita é uma forma de atualizar o projeto literário, cultural e político do escritor: não apenas falar sobre os habitantes da periferia, mas falar com eles e lhes dar a palavra.

\section{Palavras-chave}

Periferia. Dalcídio Jurandir. Migração. Cotidiano dos pobres. Teatro como forma de emancipação.

\begin{abstract}
The life conditions at the periphery of the big cities on our "Planet of Slums" are a challenge of general concern. The novelist Dalcídio Jurandir (1909-1979) deals with this problem by choosing the periphery of Belem as the scene for five of the ten novels of his Amazon Cycle (1941-1978). Here we focus on the novel Passage of the Innocent (1963), describing a scenic adaptation made with teachers and students of a school from the periphery. The main episodes are the initiation to the city of a schoolboy from the interior of Amazonia, the daily routine of the housewife who receives him in her hut, and her desire of evasion. As a counterpart to this individual wish the author introduces a political manifestation which calls attention to the chronic problems of the poor neighborhoods. The importance of this novel in Jurandir's Amazon Cycle is especially due to the relevance given to the speeches of the characters. The method of a dramatic reading described here, attempts to update the literary, cultural and political project of the novelist: not only talk about the inhabitants of the periphery, but to talk with them and hear what they have to say.
\end{abstract}

\section{Keywords}

Periphery. Dalcídio Jurandir. Migration. Daily life of the poor. Theatre as a form of emancipation. 


\section{A PERIFERIA - UM ESPAÇO SEMIESQUECIDO}

O Ciclo do Extremo Norte, composto por dez romances do escritor paraense Dalcídio Jurandir (1909-1979), continua semiesquecido pelos estudiosos da literatura brasileira. Apenas no estado de origem do autor a obra foi redescoberta pela crítica e reeditada, a partir dos anos 1990. Na verdade, isso aconteceu apenas com os três livros que retratam a ilha de Marajó - Chove nos campos de Cachoeira (1941), Marajó (1947) e Três casas e um rio (1958) - e o romance que se passa no centro da capital: Belém do Grão-Pará (1960). Alguma atenção foi dada também à última obra, Ribanceira (1978), localizada no Baixo Amazonas. A outra metade do Ciclo, cujo cenário são os bairros periféricos de Belém, continua sendo deixada à margem. Trata-se dos cinco romances Passagem dos Inocentes (1963, $2^{\mathrm{a}}$ ed., 1984), Primeira Manbã (1967), Ponte do Galo (1971), Os Habitantes (1976) e Chão dos Lobos (1976). Exceto Primeira Manbã, que foi recentemente reeditado ( $2^{a}$ ed., 2009), nenhum dos demais teve uma nova edição há quase três décadas. É como se a crítica e as editoras quisessem competir com as autoridades públicas em termos de esquecimento e descaso para com a população daqueles subúrbios. Esses excluídos, no entanto, mereceram a atenção do romancista, que viu bem que as baixadas, onde se sobrepõem as formas de vida ribeirinha e urbana, são o lugar de moradia das massas de pobres do interior, que ali se instalaram ao longo do século XX, com os movimentos de migração. Contemporâneo da explosão demográfica que começou nos anos 1960 no mundo inteiro e que resultou nas megacidades que caracterizam o nosso Planeta Favela (DAVIS, 2006), ele chama a atenção para as condições de vida na periferia, que são um desafio que afeta a todos.

O que confere um caráter paradigmático a Passagem dos Inocentes, o quinto romance do Ciclo Amazônico de Dalcídio Jurandir, é o fato de que a partir daí, Alfredo, o protagonista do ciclo, agora com 14 anos, é iniciado a viver na periferia da grande cidade. Esse será o cenário de todos os romances seguintes, e é para lá que ele sempre volta, tanto depois de suas estadias de férias no Marajó, quanto depois de sua experiência de trabalho no Baixo Amazonas, narrada em Ribanceira. Quando Alfredo, entre seus doze e treze anos, morou e estudou em Belém pela primeira vez, o que é descrito em Belém do Grão-Pará, ele conheceu as baixadas, ou seja, o território da periferia, apenas de longe. Era hospedado, então, na casa da família Alcântara, na Avenida Gentil Bittencourt, perto do Largo de Nazaré com a Basílica, ou seja, num bairro de classe média, nas proximidades de um bairro nobre. Dos fundos daquela casa ele avistava os capinzais, as "barracas" e "os alagados da baixa", em direção ao rio Guamá. Alfredo sentia, então, 
“o hálito das baixas [que] cobria o quintal” (BGP, p. 109). ${ }^{1}$ Não chegou a pôr os pés naquele território, mas os habitantes à margem da grande cidade atiçavam a sua curiosidade. "Que população vivia" naquela outra parte de Belém, "do outro lado da baixa", perguntava-se Alfredo; "que lavadeiras, capinadores com suas foices, que meninos?” (BGP, p. 248).

Para o autor deste artigo, o estudo do romance Passagem dos Inocentes coincidiu com uma experiência de contato e trabalho conjunto com habitantes da periferia de Belém. A partir do Fórum Social Mundial, realizado em janeiro de 2009, em Belém, estabeleci contato com um grupo de professores e alunos da Escola Estadual de Ensino Fundamental e Médio Dr. Celso Malcher, localizada no bairro de Terra Firme. Realizamos juntos uma oficina de leitura dramática com o referido romance de Dalcídio Jurandir, durante o segundo semestre de 2009 e o primeiro de 2010. Para o trabalho de adaptação cênica do romance - nos serviu como inspiração e orientação uma pergunta que Bertolt Brecht fez a Walter Benjamin numa conversa sobre a obra de Franz Kafka: "Quais as propostas praticáveis que podem ser extraídas de suas narrativas?" (BENJAMIN, 1971, p. 123). É legítimo transferir essa pergunta para os romances de Dalcídio Jurandir, cujo projeto literário, cultural e político pode ser caracterizado como uma tentativa, bem-sucedida, de estabelecer um amplo diálogo com as pessoas das camadas populares, no sentido de não apenas falar sobre elas, mas falar com elas e lhes dar a palavra. Esse projeto, a nosso ver, merecia ser retomado e transformado num tipo de práxis pedagógica, no caso, numa adaptação cênica do romance, com apresentações públicas seguidas de debate. ${ }^{2}$

\section{ADAPTAÇÃO CÊNICA DO ROMANCE}

Depois de um planejamento, prévio em agosto de 2009, seguido da leitura e releitura, individual e conjunta do romance Passagem dos Inocentes, o grupo realizou a confecção do roteiro cênico durante o mês de outubro. Esse trabalho de adaptação merece uma descrição detalhada. Tratava-se de transpor um romance de 276 páginas, ou seja, uma obra narrativa extensa, para o gênero dramático: no caso, um roteiro cênico sucinto, que resultou num texto de onze páginas. Optamos por essa forma breve, uma vez que a nossa ideia era oferecer para o público uma síntese de passagens essenciais do romance. A função principal

A sigla "BGP", neste texto, refere-se à Belém do Grão-Pará, 2. ed., 2004.

Um exemplo de adaptação cênica bem-sucedida foi a experiência realizada entre 2004 e 2006 com o romance Grande Sertão: Veredas, de Guimarães Rosa, com apresentações no Brasil, na França e na Alemanha. Ver a descrição detalhada na dissertação de mestrado de Maira Fanton Dalalio (2011). 
dessa transposição teatral era despertar a curiosidade e incentivar a leitura dessa obra na íntegra.

A transformação do romance num roteiro cênico solicita todas as habilidades da "arte de ler". Trata-se de compreender bem o texto, saber analisar e interpretar, conseguir resumir e extrair o essencial, selecionar e recortar cenas e personagens, enxergar os conflitos mais significativos, citar as passagens mais relevantes e as falas mais expressivas. Para o leitor ter uma ideia mais clara do nosso trabalho de transposição teatral, oferecemos em seguida um resumo do romance, em uma página; e também em uma página, uma sinopse do nosso roteiro cênico (cf. p. 4 e 5).

Ao estudar agora o romance de Dalcídio Jurandir, à luz desse roteiro cênico, vamos realizar ao mesmo tempo uma análise e interpretação da obra. Recortamos dela os três núcleos temáticos que nos parecem os mais interessantes e mais apropriados para uma apresentação teatral, confeccionando um roteiro em três atos. Como se vê, ficaram de fora da nossa seleção os capítulos inicial ${ }^{3} \mathrm{e}$ final do livro (aliás, bastante longos), cuja ação não se passa em Belém, mas na ilha de Marajó: respectivamente no Muaná (p. 9-66) e em Santana, incluindo a travessia de barco (p. 233-284). Deixamos de lado também o episódio "O jogo [de futebol]" (p. 223-231), cujo "protagonista" é a bola que cai no meio das moradias, como uma alegoria do trabalho do escritor de "vasculhar as barracas" (p. 230), isto é, a vida dos que ali habitam. Esses cortes, que reduziram de 276 para 156 o número das páginas do romance a serem adaptadas (da p. 67 à p. 222), evitaram a dispersão de temas e cenários, e permitiram uma concentração maior sobre o miolo da narrativa, que se passa na periferia de Belém. O que caracteriza o modo de vida dos habitantes das baixadas é justamente o intercâmbio constante com o mundo dos ribeirinhos, no caso, especialmente da ilha de Marajó, seja pelo trânsito físico das pessoas, seja pelas suas lembranças.

\section{RESUMO DO ROMANCE PASSAGEM DOS INOCENTES}

Os títulos dos capítulos (em negrito) e as subdivisões são do romancista; as demais informações são o nosso esboço de resumo. Os números referem-se às páginas da segunda edição de 1984.

009 No Muaná o chalé [isto é: o casal] separa-se

I. Os pais vêm com Alfredo a Muaná: Major Alberto fica na antiga casa dele, d. Amélia e o filho vão para a barraca do avô. Alfredo em busca de Andreza.

\footnotetext{
3 Do capítulo inicial incluímos, no entanto, o convite feito por d. Cecé de agasalhar Alfredo na sua casa em Belém.
} 
015 II. Alfredo em busca de Semiramis, uma menina que ele encontrou num baile.

020 III. Tio Ezequiel dá uma grande festa de recepção para a irmã, mãe de Alfredo.

038 IV. O Major descansa na rede e fica de olhos em d. Amélia.

040 V. Conversa competitiva entre d. Cecé, sobrinha do Major, e d. Amélia. Referências à fuga de d. Cecé quando moça. Ela propõe hospedar Alfredo em Belém.

\section{Caminho da Mac-Donald}

(2.a) chegada de Alfredo, com 14 anos, em Belém. Para sua decepção, ele não está hospedado num bairro nobre, mas numa barraca da periferia, nos "Covões".

\section{Anos atrás na fuga a bordo}

[I.] D. Cecé/Celeste na barraca: recordando a noite do baile a bordo, quando foi raptada pelo comandante. Na volta, Antonino Emiliano aceitou casar-se com ela.

100 II. Celeste abre a mala com os vestidos e reconstrói a viagem com a imaginação.

\section{Caminho do [grupo escolar] Barão}

I. Alfredo mora na Passagem dos Inocentes, na barraca de d. Cecé. Seu Emiliano para o filho: "Belerofonte, monta no (porquinho) Pégaso e mata a Quimera!"

110 [II.] Alfredo continua estudando no Barão: ele acha as aulas um tanto abstratas.

122 III. D. Celeste prepara-se para dar o seu passeio de $4^{a}$-feira.

123 IV. D. Cecé define as regras para Arlinda, a criada. Travessuras de Belerofonte.

\section{D. Celeste a bordo}

Ela reabre a mala com os vestidos, recorda a viagem, os momentos mais significativos de sua vida sentimental e sonha com suas várias possibilidades de ser.

\section{Belerofonte é belo}

O cotidiano de Alfredo na barraca, ao lado do menino travesso Belerofonte.

$175 \mathrm{O}$ passeio, a mosca e os anjos

[I.] No bar, Cara-Longe comenta os passeios de d. Celeste às $4^{\text {as }}$ feiras, o acúmulo de lixo na cidade, que traz a praga das moscas e causa a morte de crianças. 
189 [II.] Alfredo torna-se confidente de seu Antonino, marido de d. Celeste.

192 [III.] D. Celeste sai para o seu passeio e Alfredo a segue, às escondidas.

201 [IV.] Manifestação do povo contra o descaso das autoridades com os problemas da cidade. Repressão pela cavalaria.

218 [V.] Antonino fala para Alfredo de seus planos: vender os pertences de d. Cecé.

223 O jogo

A bola que cai nas barracas é uma alegoria da sondagem do escritor nesse meio.

\section{Noite em Santana}

-284 Tio Sebastião leva Alfredo de barco para Marajó. Festa em Santana.

Ali nasce uma criança e o adolescente Alfredo é iniciado ao baile.

\section{SINOPSE DO ROTEIRO CÊNICO DE PASSAGEM DOS INOCENTES}

Em negrito, os títulos que atribuímos aos atos e às cenas. Os números de páginas são as do roteiro.

Cena inicial: Cantiga de roda e apresentação do protagonista (p. 1):

Alfredo, um quase rapaz de 14 anos da Ilha do Marajó, chega em Belém para continuar seus estudos

Primeiro Ato (p. 2-3):

Introdução à periferia

Convidado por dona Celeste a hospedar-se na casa dela em Belém, Alfredo desembarca, acompanhado do irmão dela, o Leônidas. Para sua decepção, a casa não se situa num bairro nobre, mas é uma barraca nas baixadas, ou seja, nos "Covões".

\section{Segundo Ato (p. 3-7): A rotina do cotidiano na periferia}

Cena 1: Dona Cecé na sua barraca

Breve conversa de d. Cecé com a vizinha: ela exibe o seu filho Belerofonte, que ela adora e trata com mimo especial, sendo que se trata de um menino bem travesso.

\section{Cena 2: A patroa define as regras para a empregada}

Arlinda, a empregada, uma moça que veio do interior, recebe as ordens e as humilhações por parte da patroa, que é a dona Cecé ou dona Celeste. 
Cena 3: Dona Celeste recorda a cena que viveu aos 18 anos: o baile e a fuga a bordo

No meio da noite, ela fica diante do espelho e põe o vestido que usou naquela noite, quando foi a um baile num navio, que acabou numa fuga junto com o comandante.

\section{Cena 4: Matando a Quimera}

É a reação do marido, seu Antonio Emiliano, que incentiva o filho Belerofonte a "matar a Quimera", ou seja, a rasgar o vestido que simboliza a lembrança daquele baile.

\section{Terceiro Ato (p. 8-11): Desejo de evasão e manifestação política Cena 1: As fofocas}

Alfredo escuta os comentários do bêbado Cara-Longe e de duas mulheres da vizinhança sobre o passeio que dona Celeste costuma dar ao centro de Belém, sempre às $4^{\text {as }}$ feiras.

\section{Cena 2: $\mathbf{O}$ comentário de seu Antonino}

O marido de d. Celeste revela a Alfredo os seus planos de vingar-se da esposa.

Cena 3: Aula sobre a geografia e história de Belém, ou:

O misterioso passeio de dona Celeste

Paralelamente ao passeio de dona Celeste, que é seguida às escondidas por Alfredo, montamos uma aula de geografia e história sobre os lugares por onde ela passa.

\section{Cena 4: A manifestação popular: a cidade e seus problemas}

Uma multidão de manifestantes se interpõe no caminho de Alfredo, impedindo-o de seguir dona Celeste. O povo protesta contra o descaso das autoridades com os problemas da cidade: o acúmulo de lixo que traz a praga das moscas e causa a morte de muitas crianças.

\section{CENÁRIO E CENA INICIAL}

Um fator fundamental para motivar os participantes da nossa oficina dramática a ler e a discutir o romance de Dalcídio Jurandir, cuja ação se passa nos anos 1920, foi o fato de ele tratar de temas que ainda hoje têm a ver com 
a experiência cotidiana deles, enquanto moradores da periferia. Um exemplo concreto disso é um trecho do romance em que o narrador fala da "empinação de papagaios":

"Alfredo arrastou Belerofonte para a empinação dos papagaios. Linhas tesas e altas cruzavam o ar quente da Passagem. [...] Os papagaios no ar." (INO, p. 126). ${ }^{4}$

Essa passagem nos inspirou a construir o nosso cenário e a cena inicial. Ligamos essa referência literária com o fato de que muitos meninos da periferia são mestres em empinar papagaios - e também em construir esse brinquedo e suas variantes: as "pipas" e as "rabiolas". Tanto assim, que os cinco "papagaios" utilizados como cenário foram confeccionados por um dos alunos participantes, o Gilvan. Nas duas pipas exibidas nas extremidades do palco, colocamos os nomes de bairros da periferia: "Guamá", o território dos excluídos, que é várias vezes citado no romance Belém do Grão-Pará (1960), e "Terra Firme", o bairro vizinho, onde vivem os nossos participantes. Nas três rabiolas do meio apresentamos os títulos de três dos cinco romances de Dalcídio Jurandir que se passam nos subúrbios: Ponte do Galo, Chão dos Lobos e a obra aqui encenada: Passagem dos Inocentes. Com isso, apresentamos topográfica e ludicamente uma imagem emblemática da periferia.

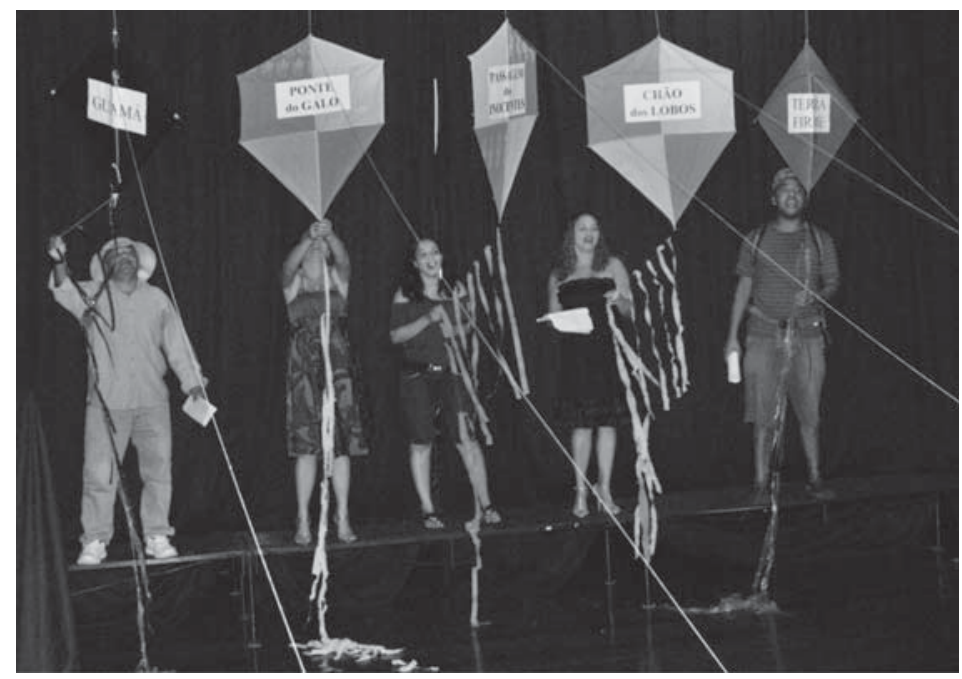

Foto 1: O Cenário.

A primeira "fala" dos cinco atores que abrem a cena, cada um deles segurando um "papagaio", é uma cantiga de roda que extraímos do romance,

\footnotetext{
$4 \quad$ A sigla "INO", neste texto, refere-se à Passagem dos Inocentes, 2. ed., 1984.
} 
substituindo apenas a expressão "ofício de conversador" por "ofício de aprendiz", que nos parece mais adequada para caracterizar o papel do protagonista Alfredo:

"Que ofício dá pra ele

Mando tiro, tiro lá

O ofício de aprendiz

Mando tiro, tiro lá

Este ofício já me agrada

Mando tiro ...” (INO, p. 70)

Para estabelecer também uma ligação física entre os atores e o público, fizemos com que os fios das pipas e das rabiolas erguidas no palco fossem "puxados" por alunos da escola, distribuídos pela plateia.

Em seguida, faz-se ouvir a voz do narrador, que apresenta para o público o protagonista e o tema do romance: Alfredo, um "quase rapaz" (cf. INO, p. 67) da ilha do Marajó, chega em Belém para continuar seus estudos. Como esclarece ainda o narrador, o jovem foi convidado a hospedar-se na casa de uma sobrinha do pai, precisamente dona Celeste. Eis a fala em que ela formula o convite, no finalzinho do primeiro capítulo do romance, que se passa em Muaná:

[D. Cecé:] “- Hein, Amélia, e o teu cavalheiro? Onde teu filho está parando agora na cidade? Qual a casa? Tu queres, eu agasalho ele lá na minha, está no teu querer, afinal é casa dum parente, tu resolves, rapariga. Não, tio Alberto? Passa por lá em casa, que a gente ajusta [...]." (INO, p. 66).

O narrador conclui a apresentação com algumas breves citações complementares, já referidas, do romance anterior, Belém do Grão-Pará, relembrando que esta é a segunda estadia de Alfredo na capital, cujos subúrbios, por enquanto, ele conhece apenas de longe. Com isso, está criado o clima para o segundo contato do protagonista com Belém, que é narrado detalhadamente no capítulo "Caminho da Mac-Donald" (p. 67-82).

\section{UMA INICIAÇÃO À PERIFERIA}

Esse episódio simboliza a experiência histórica de centenas de milhares de jovens que migraram, ao longo do século XX, do interior da região amazônica para a capital, Belém, movidos pelo desejo de aí obter uma boa formação escolar, um trabalho e uma melhoria geral de suas condições de vida. A introdução de Alfredo à sua moradia por Leônidas, o irmão de dona Celeste, é um verdadeiro ritual de iniciação ao mundo da periferia, em que o protagonista se despede de suas expectativas e ilusões. Se a lembrança de sua primeira chegada à cidade, em companhia da mãe, foi de "feliz espanto". Nesta segunda vinda, ele sente 
"uma curiosidade triste" (p. 67). Vamos acompanhá-lo passo a passo e, com isso, também conhecer os detalhes topográficos.

Vindos de Muaná, Alfredo e Leônidas desembarcam ao cair da tarde no Ver-o-Peso. Lá eles tomam o bonde circular, descendo no Umarizal, na parte setentrional, em direção ao bairro vizinho, do Telégrafo, "na travessa D. Pedro, esquina da Curuçá” (p. 67). Como o Umarizal é hoje em dia o bairro mais valorizado de Belém, é preciso lembrar que, meio século atrás, o seu perfil era bastante diferente - e mais ainda naqueles anos 1920. É o que nos faz ver o geógrafo Antonio Rocha Penteado, que o caracteriza como "um bairro de transição":

"[...] seu trecho meridional, em contato com Nazaré [...], obedece ao traçado dos bairros mais elegantes de Belém [...]. Mas, à medida que caminhamos para o norte, seguindo a Av. Generalíssimo Deodoro e penetrando pela Trav. D. Pedro [...], vai decaindo o padrão das moradias e, gradativamente, as 'barracas' se tornam cada vez mais freqüentes." (PENTEADO, 1968, p. 337).

Esse quadro topográfico da antiga parte norte do Umarizal torna-se ainda mais desfavorável quando se caminha em direção ao bairro vizinho, situado às margens do igarapé do Galo:

"Essencialmente residencial de classe pobre, tem sua estrutura desordenada, bem marcada por ruas tortuosas, cheias de mato e água empossada nas partes baixas [...]." (PENTEADO, 1968, p. 342).

Essa fisionomia é muito parecida com a do subúrbio onde o nosso romancista situa a "Passagem dos Inocentes" e para onde leva o protagonista.

Depois de descer do bonde, Alfredo procura orientar-se nesse espaço. De um lado, "lá adiante na curva do Circular", "engolido pela noite", ele enxerga "O muro do Esquadrão, que dava nome ao largo" (INO, p. 67). Uma consulta à história das ruas de Belém nos ensina a origem do nome: nesse largo foi instalado, no final do século XIX, o quartel do esquadrão de cavalaria da Polícia Militar do Estado. Mais tarde, o Largo do Esquadrão foi rebatizado de Praça Brasil e, mais recentemente, de Praça Santos-Dumont (cf. VALENTE, 1993, p. 6263). Do outro lado, seguindo pela travessa D. Pedro, Alfredo alcança o largo de Santa Luzia" (cf. INO, p. 69). Com esse nome era designado o "seccionamento da rua Bernal do Couto pela travessa Dom Pedro I e [a continuação desta, a] avenida Generalíssimo Deodoro". Ali situa-se até hoje a Santa Casa de Misericórdia, inaugurada em 1900, ${ }^{5}$ mas o nome do largo "perdeu-se na poeira

5 A Santa Casa é relembrada por Alfredo, uma vez que ali, na Maternidade, a sua mãe teve a sua irmã Mariinha (cf. INO, p. 77). 
do esquecimento” (VALENTE, 1993, p. 58-59). A impressão geral de Alfredo, ao chegar nesse ambiente, é que "aquela paragem ali, apesar da linha de bonde, boa cara não tinha” (INO, p. 67).

Tomando agora o "caminho da [passagem] Mac-Donald", como anuncia o título desse capítulo, Alfredo repara, no acender das lâmpadas, que a da esquina da rua Curuçá está queimada. Mas, por enquanto ele está cheio de expectativas em relação ao lugar onde irá morar e dá asas à imaginação:

“O meu hóspede, dizia a d. Cecé ao despedir-se dele, Alfredo, em Muaná. Espero lá o meu ilustre hóspede. Alfredo palpitava: E a casa lá? Como será? Alta? De platibanda? Telha francesa? Soalho madeira preta e branca? Sacadas." (INO, p. 68).

Ocorre que o caminho pelo qual o leva Leônidas não condiz de modo algum com essas expectativas, e Alfredo começa a desconfiar:

"O chuvisco [...] voltava. A rua, sem calçamento, cavada pelas chuvas, escorregava, com uns passeios de quina roída, aqui e ali, rente das barracas; no passo do caminhante, [...] lá no capinzal sob um grunhir de porco e sapo, a escuridão [...].” (INO, p. 70).

Esse ambiente inóspito é o avesso do padrão de vida que dona Celeste ostentava em Muaná: o de uma senhora fina, morando numa "casarona" de azulejos. Quanto ao endereço dela em Belém, Alfredo ouviu dizer que ela o ocultava de propósito. E ele lhe dava razão, pois era

\footnotetext{
"para se livrar [...] daqueles do interior que, de tanto se meterem, dias, em casa alheia em Belém, já faziam disso um ofício. [D. Celeste] esquivava, falava assim: -Ali, no Umarizal, onde moro, moramos, eu gosto. [...] É na Passagem Mac-Donald. [...] Enchia a boca de Mac-Donald. O número da casa? Não te digo.” (INO, p. 69).
}

Durante algum tempo, Alfredo até pode imaginar que o desconforto do caminho por onde o leva o irmão de dona Celeste, a partir do momento em que "entram na [rua] Curuçá" (p. 79), faz parte da dificuldade de encontrar o lugar. Eis alguns fragmentos de diálogo, que usamos em nossa adaptação (com pequenos cortes e leves modificações), aproveitando o fato de que já têm um caráter de interação cênica, com a tensão entre as hesitações e o receio do protagonista, e, por outro lado, as palavras tranquilizadoras, embora levemente irônicas, do seu guia $(\rightarrow$ foto 2$)$ :

Leônidas: - É aqui. Aqui se entra.

Alfredo: - Aqui? Mas isso aí dentro?

Leônidas: - Muito escuro? Não tenha medo, vais comigo.

Alfredo: - Não é medo. Mas tem de passar por aí para chegar lá? 


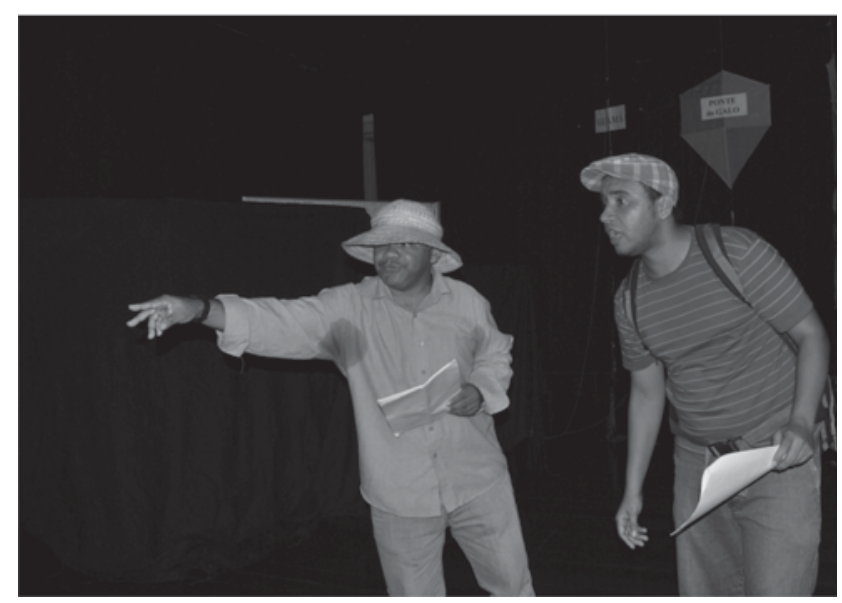

Foto 2: Iniciação de Alfredo à periferia.

Leônidas: - Na Cecé? Na Celeste? Mas é por aqui, é aí dentro.

Alfredo: - Mas pra ir para lá, precisa mesmo entrar aqui? Por esta boca?

Leônidas: - Meu filho, é aqui, nesta Passagem que Celeste mora. Por aquela boca, o caminho vai dar lá, na Celeste, o teu Grande Hotel, meu viajante. A Inocentes.

Alfredo: - Inocentes?

Leônidas: - A Passagem dos Inocentes, sim, onde tu vais morar. Celeste mora. Pra onde vamos. (cf. INO, p. 79-80).

Nesse momento é citado o nome da passagem que dá o título ao romance. Chegou-se ao ponto em que os fatos reais - o caminho encharcado e os pés afundando na lama - obrigam Alfredo a desfazer-se de suas ilusões. Ele, porém, é relutante e ainda quer apegar-se aos padrões dos bairros residenciais burgueses e das avenidas nobres como a São Jerônimo e a Nazaré, onde chegou a morar durante a sua estadia anterior:

“A Inocentes? A Passagem? Mas d. Cecé lá [em Muaná], não dizia que nome de Passagem se dava em Belém a trechos calçados, que ligavam ruas, como aquela entre São Jerônimo e Nazaré, [...] a Passagem Mac-Dowell.” (INO, p. 80).

De fato, naquele bairro fino, entre a Av. Brás de Aguiar e a Gentil Bittencourt, existe até hoje uma Passagem Mac-Dowell, nome muito parecido com o da passagem mencionada por dona Celeste. Por isso, Alfredo pergunta: “ - Mas não é a Passagem Mac-Donald, Leônidas?” Este, então, esclarece-lhe que a sua irmã inventou e fantasiou um pouco, para exibir-se diante das pessoas no interior, usando para isso um nome em inglês; ao mesmo tempo, ele dá a 
entender que de Alfredo, se fosse menos ingênuo, bem que poderia ter percebido isso já naquela hora:

“ - A Mac-Donald? Ah, o inglês? Celeste imagina muito, é. [...] Foi a figuração da Cecé. Aquela minha senhora irmã. E tu não sabias? Sim, lá no Muaná, ao certo não se sabe. Cecé lá é uma coisa, aqui é outra. Cecé, lá, disto nunca diz. Oculta. Sabias?” (INO, p. 80).

À medida em que os dois caminhantes avançam em direção à Passagem dos Inocentes - um nome simbólico que o autor inventou e que, pelo contexto, se refere a uma das travessas entre a rua Curuçá e a Travessa Quatorze de Março ${ }^{6}$ (perto do igarapé do Galo) - completa-se a desilusão do protagonista:

"Ao cruzarem a entrada, a vala se escancarou, uma goela que podia levar os dois [...] até lá em baixo, nas casas sepultadas. Casas? Ali na boca se via um palhame grosso, arrepiado, encharcado. [...] e logo a passagem se estreitou, buracos, valas, capinzal [...]. E chovendo em cheio em cima dos viajantes os carapanãs num zinido em grosso, disparavam de todos os lados" (INO, p. 80-81).

Leônidas, que já está familiarizado com esse lugar desolador, procura animar Alfredo, inclusive com alguns gracejos:

“- Não esmorece, caminhante, o tempo é que está danisco. [...] Mas nesta lama [...] é carapanã, é sapo, é gato, a banda de música da Inocentes nos recebendo, companheiro..." (INO, p. 80-81).

Alfredo, que nesta altura já "mal andava, se abanando", percebe que “aquela população ali” em volta está “entocada como sapo”. Na escuridão, onde quase nada se enxerga, ele afunda na lama e começa a se revoltar:

"Porta de inferno, te abre, te apresenta, casa do são nunca. / Leônidas quis pegá-lo pela mão, guiá-lo, ele se arredou, rejeitou o amparo, metendo então bem fundo o pé, sapato e meia, no lamaçal. Arrancou a perna como se a trouxesse podre, esmagada cheia de bicho. [....] a lama na perna, os bichos lhe subindo, mandava a d. Celeste, a casa dela, o estudo, a cidade para as profundas" (INO, p. 81).

No final, Alfredo encontra "de repente a palavra para aquilo tudo". Ele a ouviu várias vezes, durante a sua primeira estadia em Belém, da boca de sua anfitriã, dona Inácia Alcântara: uma palavra de dar arrepios. Essa palavra, enfaticamente repetida (e que reproduzimos aqui no mesmo padrão gráfico do texto original, p. 82), designa “o derradeiro, triste-triste grau de se morar":

${ }^{6}$ Eis o que diz o texto, mais adiante: "Podia sair e entrar na Inocentes pela boca de cima, pela Curuçá, mas [...] quebrava aqui por baixo pela Quatorze [...]” (INO, p. 122). 
"Covões. Covões. O juízo lhe diz:

Covões.

COVÕES

COVÕES.

Com isso, completa-se a iniciação do protagonista à periferia.

\section{A ROTINA DO COTIDIANO E A RECORDAÇÃO DE UM BAILE}

No nosso segundo recorte - ou segundo ato - focalizamos alguns aspectos da rotina cotidiana de dona Cecé na sua barraca. Na verdade, é ela que é interpretada por três atrizes diferentes - que passa a ser a protagonista do romance. Ela representa a figura de mediação entre a Amazônia ribeirinha e a urbana, como também entre os bairros da periferia, onde vivem os pobres em suas barracas, e os bairros nobres, onde residem os ricos e os remediados. Com isso, a personagem resume um aspecto significativo de todo o Ciclo Amazônico de Dalcídio Jurandir. ${ }^{7}$ Cabe a Alfredo em Passagem dos Inocentes, sobretudo, o papel de observador participante, como no capítulo "Belerofonte é belo" (INO, p. 167174), que escolhemos como a primeira das quatro cenas da nossa adaptação dessa parte. Enquanto Alfredo prepara em casa as suas tarefas escolares, ele observa como o filho de dona Cecé, Belerofonte, compraz-se em tiranizar a empregada:

"Atrás dela com tranco, cuspo, mordida, pontapé beliscão vou te meter num saco te atirar na carrocinha dos cachorros, [...] - sapateava o Belerofonte - Arlinda abria a boca, abria? Com aquele não ter língua seu falar era servir" (INO, p. 171).

Esse menino é muito mimado pelos pais, que não lhe põem nenhum limite, mas estimulam a sua agressividade. A mãe idolatra o filho e o exibe com orgulho. O mote do título, "Belerofonte é belo", é repetido por ela várias vezes:

“ - Alfredo, não achas que o meu filho é belo? Não tem um garbo? Talhado para um oficial de Marinha? Deus me diz que a danação dele, que tem, é sinal de homem, é ou não é?" (INO, p. 171).

“- Meu filho é belo. Destino dele é a Marinha, no navio-escola correndo os mares, me mandando retrato e os cartões do vulcão Vesúvio. / Falava do filho como se o tivesse gerado dum capitão de encouraçado inglês que passasse uma noite por Belém. Não dizia nem bonito nem lindo dizia belo. E dizia com voz cheia e doçura. / - Tu não achas, Alfredo? Pena que não há mais no mundo homens belos" (INO, p. 171).

Estas observações baseiam-se na comunicação de Anna Carolina de Abreu Coelho (uma das nossas três atrizes que interpretam a dona Celeste), "Representação da Periferia de Belém na obra Passagem dos Inocentes", apresentada no XVI Fórum Paraense de Letras, na UNAMA, em 26/10/2010.

Novos Cadernos NAEA •v. 15 n. $2 \cdot$ p. 217-246 • dez. 2012 
"De que filho ela falava?" pergunta-se Alfredo, que entende que "não era mais do filho que d. Celeste falava, mas dela mesma". De fato, dona Cecé agarra-se obsessivamente às suas fantasias. Ou, melhor, à sua mitologia, uma vez que Belerofonte é um nome tirado da mitologia grega. No canto sexto da Ilíada (versos 155-203) Homero narra o mito do herói Belerofonte, o qual, montado no cavalo alado Pégaso, mata o monstro da Quimera, que tem cabeça de leão, corpo de bode e cauda de serpente. Dona Cecé e o seu marido, seu Antonino Emiliano, estão obcecados por esses nomes: ela, deslumbrada com o seu "Belerofonte", e ele, "arrotando sobre um livro de mitologia" (cf. INO, p. 184), referindo-se a todo momento à "Quimera", ao "Pégaso" e ao "Zéfiro" (o vento suave e benfazejo do Oeste). Devemos estranhar esses nomes da mitologia grega na boca de habitantes não letrados da Amazônia? Afinal, eles são também um meio através do qual o escritor nos faz relembrar que toda essa região vive mergulhada em mitos, a começar pelo seu nome. No referido canto da Ilíada (verso 186), Belerofonte aparece também como aquele que "matou a tribo das Amazonas", que são qualificadas no texto original como antianeirai. Como traduzir esse epíteto, que Homero aplica às Amazonas também no verso 189 do canto terceiro: como "semelhantes a homens" ou "anti-homens"? Ambas as traduções são válidas. E existe ainda uma terceira solução, a tradução engenhosa deste último verso por Haroldo de Campos: "másculas, adversas". O conjunto dessas três traduções forma uma constelação semântica multifacetada que enriquece o texto. ${ }^{8}$

O contraste entre os nomes insignes da mitologia grega e a trivialidade do cotidiano de dona Cecé e de sua família provoca no leitor uma reflexão crítica sobre as condições de vida desses personagens que se refugiam em idealizações: pois o "Zéfiro" é o barco de aluguel com o qual seu Antonino não consegue ganhar o sustento da casa (cf. INO, p. 190); o "Pégaso" é "o capadinho que a d. Celeste cevava para o dia do Círio" (p. 107); a "Quimera” são as fantasias cultivadas por uma dona de casa da periferia, frustrada com sua vida rotineira pobre e sem perspectivas; e "Belerofonte", segundo a visão crítica e desmitificadora de Alfredo, é "o malino escorrido e escarrado" (p. 173).

O papel de observador participante cabe a Alfredo também no capítulo "Caminho do [Grupo Escolar] Barão [de Rio Branco]" (INO, p. 103-128), onde é descrito o modo como Arlinda, uma menina recém-chegada do interior, é tratada pela dona da casa (p. 123-128). Note-se que os estudos formais na escola são para o protagonista apenas o pano de fundo para a sua aprendizagem das relações sociais. Nessa cena, em que a patroa define as regras para a empregada,

\footnotetext{
Seriam as mulheres guerreiras e independentes dos homens, nos romances de Dalcídio Jurandir, recriações das Amazonas? É uma questão que mereceria um estudo à parte.
} 
trata-se de um tipo de relação de trabalho, que, muito além de alguns detalhes característicos da região amazônica, é representativo para o Brasil inteiro.

“- Aqui esta meã afilhada, Alfredo, vem ajudar no serviço, veio do sítio. Eu estava na falta duma. Arlinda, agora, ouve qual tua obrigação. Treze, tua idade, é? Teu tio me falou. [...] Estás e não estás na casa alheia, vieste me servir, [...] servirzinho um pouco o bastante que quero para movimento de fogão, encher o pote, rachar um pau de lenha, o lixo na baixa, a vigiação do porco, o asseio no quintal, atender ao Belerofonte, ir numa compra, tirar de minha mão certos cuidados" (INO, p. 123-124).

A condição das empregadas domésticas na sua forma mais crua, que se configura como um trabalho escravo, já apareceu como tema em romances anteriores do autor. Em Marajó (p. 315-316), a menina Rita conta como quase foi entregue pelos pais para um canoeiro que a negociaria como mercadoria no Ver-o-Peso. É o que acontece efetivamente em Belém do Grão-Pará (p. 83-84), com "uma menina de nove anos, amarela, descalça [...], metida num camisão de alfacinha", que é examinada, numa transação com um canoeiro, como "encomenda" e "mercadoria" por uma senhora da classe alta, que procura "uma maiorzinha para serviços pesados" e acaba recusando aquela menor, a qual ela se refere como "isto aî" e "bicho do mato". No mesmo romance, uma das figuras principais é Libânia, "uma serva de quinze anos, trazida, muito menina ainda, do sítio pelo pai para a mão das Alcântaras" (BGP, p. 51-52). Como bem explica Marlí Furtado (2010, p. 118-119), em sua análise dessa personagem, ela é mantida pelos Alcântaras como uma "filha de criação", o que é uma forma "maquilada das relações escravistas", pois "como a filha de criação não é empregada, não tem salário, e como não é filha, o trabalho é sem tréguas". É exatamente o que dona Cecé faz com a sua "afilhada" Arlinda: além de explorá-la como cozinheira, faxineira e babá, ainda a incumbe de múltiplos outros trabalhos braçais, como abastecer a casa, rachar lenha e vigiar o porco. O rebaixamento da moça à condição de escrava não poderia ser mais humilhante, de modo que esse episódio ilustra de modo exemplar o que Walter Benjamin (1984, p. 188) denominou "história dos sofrimentos".

O tema principal do romance, como mostram os capítulos centrais, são as recordações, os desejos e os devaneios de uma dona de casa na periferia, que quer escapar de um cotidiano que lhe é insuportável. Esses episódios, intitulados respectivamente "Anos atrás na fuga a bordo" (INO, p. 83-102) e "D. Celeste a bordo" (p. 129-166), são emoldurados por cenas prosaicas que caracterizam o ambiente da barraca e que já descrevemos: a chegada de Alfredo na Passagem dos Inocentes e o dia a dia de moradores como o menino Belerofonte e a empregada 
Arlinda. Em certas noites, enquanto seu filho dorme e o marido está roncando, dona Celeste se levanta e vai para a sala, para recordar uma cena que viveu quando tinha dezoito anos e que foi a mais marcante de sua vida. Um navio tinha atracado em sua cidade natal, em Muaná, na ilha de Marajó, e a bordo realizou-se um baile. No auge da festa, noite profunda, ela teve "a cintura enlaçada" pelo braço do capitão e começou "aquele primeiro rodopio no salão", o navio desatraca e parte para dentro do labirinto fluvial do rio Amazonas. Essa noite é recordada por Celeste, que podemos imaginar com o vestido do baile na frente do espelho e começando a dançar. Ela quer reviver a atmosfera daquele baile:

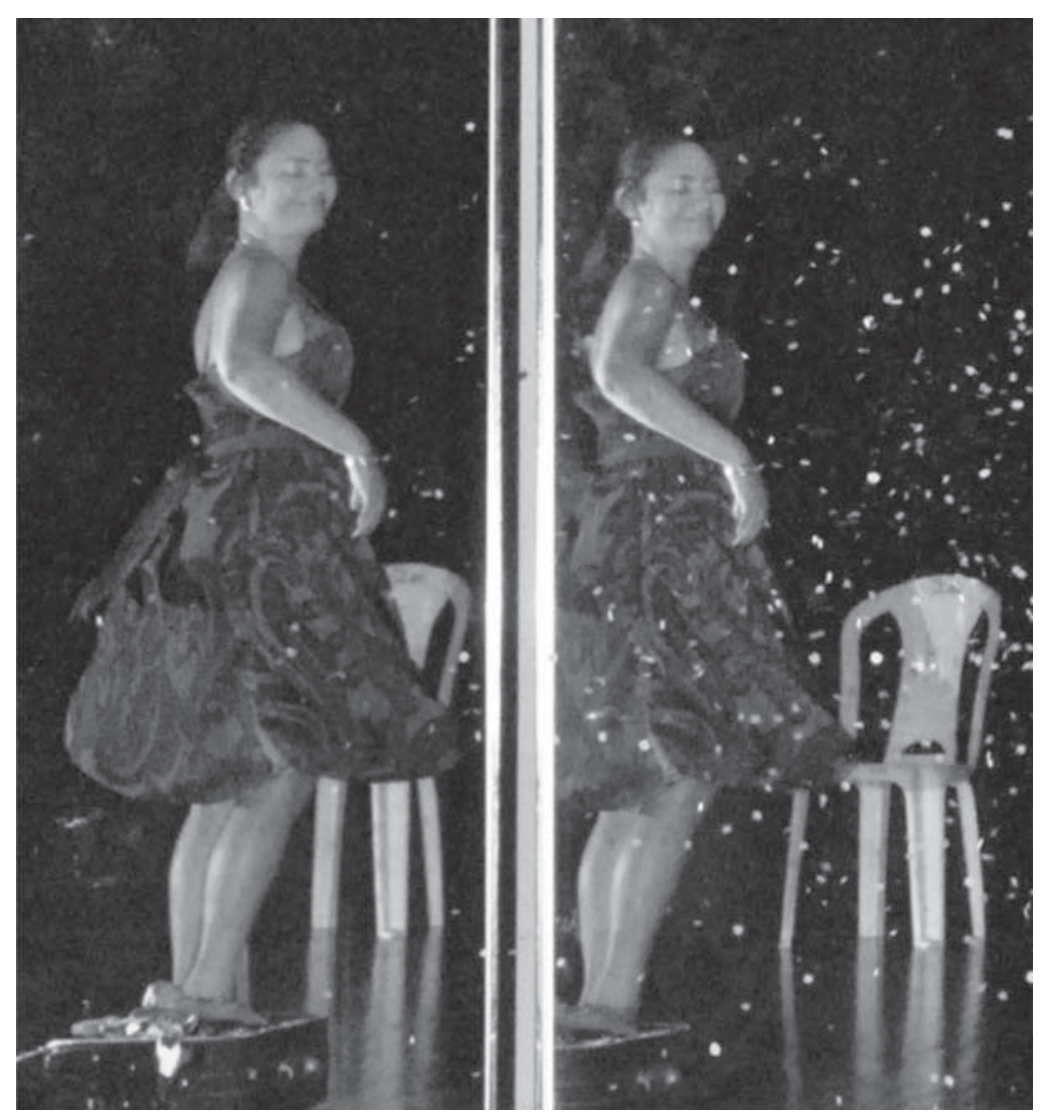

Foto 3: Recordando o baile.

"E valsa em cima de valsa, [...] a dama levava o seu baile para o meio do rio, soalho macio era a maré agora seu salão [...]. Lá me vou, Cecé, com o meu vestido de ar [...], valsando sobre igapós, lagos, cemitérios dos índios, em meio do laço no ar que os vaqueiros me atiravam [...], faço o meu baile nas águas grandes [...], o navio subindo, Manaus, Solimões, [...] o comandante, comandando nesta roda de leme que é este meu corpo [...], [passando pelas] cidades com seus arraiais embandeirados [...], as 
vilas cheirando a febre e a baunilha, os portos de lenha, castanha e um São Bendito esmolando, o urro dos bois na maromba e o silêncio dos caçadores no só Deus quem sabe do mato, o lodo e a aninga [...], e a rabuda arara carregando no bico a cauda do vestido de baile, o baile da Celeste Coimbra de Oliveira, família de nome no Muaná” (INO, p. 85-86).

Essa recordação e reinvenção do passado corresponde ao que Freud chama de "lembranças encobridoras" (Deckerinnerungen), sendo que, nesse caso, o termo original alemão é espantosamente preciso, pois esta palavra pode ser traduzida também por "lembranças do convés" ou "lembranças do tombadilho", literalmente: "lembranças do deque". Para reviver aquela cena, Celeste abre a mala em que guarda "os vestidos velhos", "os vestidos de Muaná", que lhe ajudam a "reconstituir a fuga a bordo", a "reaver com a imaginação os fragmentos perdidos, como se neles quisesse captar o melhor de sua aventura" (cf. INO, p. 100-101). Esse ritual é muito parecido com um exercício que se pratica nas escolas de arte dramática, o chamado "exercício do baú", em que o ator ou a atriz, por meio de objetos que usou no passado, reconstitui elementos significativos de sua vida emocional.

No caso de dona Celeste, vêm à tona todos os sentimentos e todas as emoções importantes que ela experimentou em sua vida: a sua felicidade quando nadava e mergulhava, "moça nua", com as amigas na enseada do rio, sentindo-se a “mãe d'água", um prazer interrompido pela repressão por parte de sua mãe (INO, p. 85); o namoro, às escondidas, com Antonino Emiliano, que depois tornou-se o seu noivo (p. 91); a raiva que ela teve dele, porque não compareceu ao baile (p. 84); o choque que lhe causou uma cena que ela observou na noite do baile, no quintal de sua casa, debaixo das bananeiras, algo que ela jamais imaginaria e que torna relativas todas as proibições (p. 83-84); ${ }^{9}$ o baile a bordo, que terminou numa viagem em que ela foi meio sequestrada, e a qual meio consentiu, noite em que "dançava nem para o lado do escândalo, nem do lado da inocência" (p. 134); uma sensação nunca antes experimentada de embriaguez dos sentidos, de vertigem, encantamento e liberdade (p. 101); a diminuição de seus sentimentos por Antonino (p. 90 e 135); a lembrança de um padre que se apaixonara por ela e que, do púlpito, proferiu um sermão que soava como "declaração de amor" (p. 137); o ritual de passagem pelo local do Vira-Saia, no Estreito de Breves (p. 150-154); uma estadia com Antonino Emiliano no Grande Hotel, em Belém,

9 O mistério dessa cena, que é mantido no primeiro episódio da fuga a bordo, acaba sendo revelado no episódio posterior, quando o tema é retomado. O que choca profundamente a Celeste é que debaixo daquelas bananeiras ela vê uma "mulher de escuro matando a sede num homem", sendo esse homem o manhoso e galante coletor federal, e a mulher, a dona Teodora Coimbra de Oliveira, esposa do juiz, dr. Felício de Oliveira, a sua própria mãe (cf. INO, p. 155).

Novos Cadernos NAEA • v. 15 n. 2 • p. 217-246 • dez. 2012 
quando ele novamente se afastou e ela se viu cortejada por um estrangeiro loiro, o piloto de um navio inglês (p. 158-162); o casamento e a noite de núpcias com Antonino Emiliano, em que este "só encontrou a gelada virgindade" (p. 163). Tudo isso, em meio a uma evocação poética de um rio mítico, com a mãe d'água, a boiúna e a carruagem de ouro dos cavalos marinhos - o rio Amazonas, pelo qual ela vai subindo até o coração da floresta e com o qual ela, Celeste, acaba se identificando e se fundindo.

Ora, a construção de ficções e fantasias por parte dos personagens de Dalcídio Jurandir, é geralmente seguida pela sua desmontagem. É o que ocorre também nesse caso. O sonho de dona Celeste é bruscamente interrompido - e com isso já passamos para a nossa cena seguinte - pelo grito do marido que incentiva o filho Belerofonte a cavalgar no porco Pégaso e a "matar a Quimera" (INO, p. 107), isto é, a rasgar em pedaços o vestido que simboliza a lembrança daquele baile.

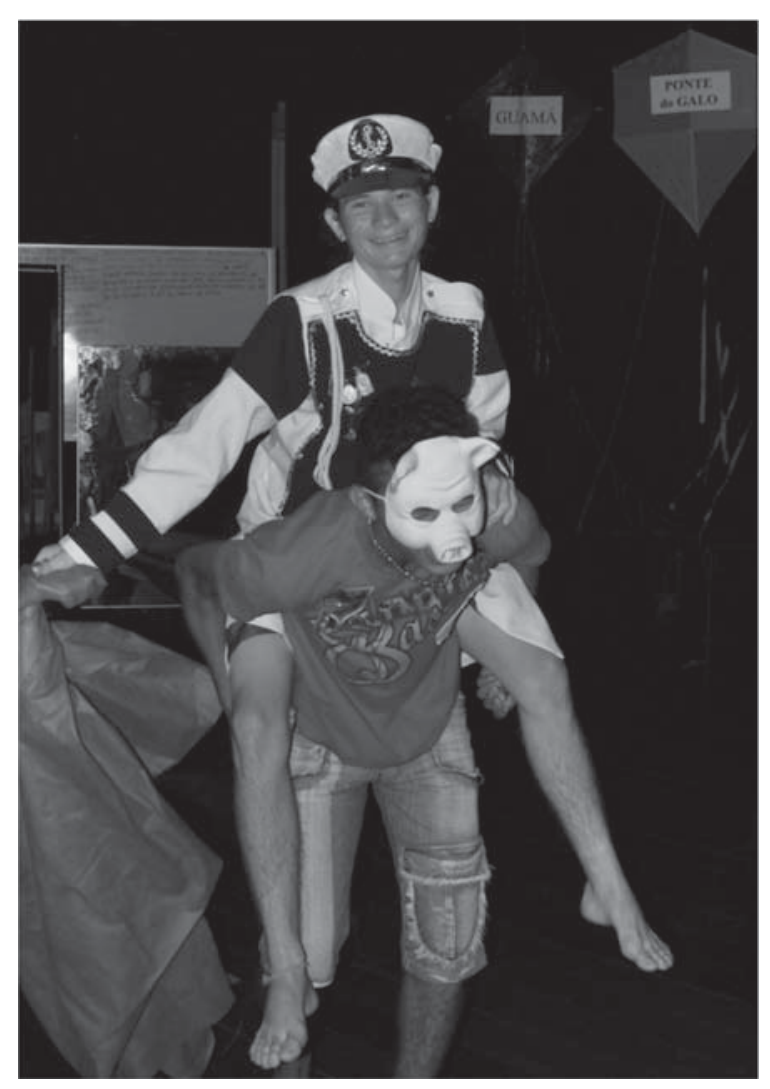

Foto 4: "Mata a Quimera!" 


\section{SONHO DE EVASÃO E MANIFESTAÇÃO POLÍTICA}

A outra tentativa de evasão de dona Celeste é um passeio que ela faz todas as quartas-feiras ao centro da cidade. É o tema do capítulo "O passeio, a mosca e os anjos" (INO, p. 175-222), do qual fizemos uma adaptação no nosso terceiro e último ato, subdividindo-o também em quatro cenas. Na primeira cena, focalizamos a repercussão que o passeio misterioso dessa senhora casada causa entre os vizinhos; eles especulam sobre os lugares para onde ela vai e sobre os homens com os quais ela talvez se encontre. Também nesta obra, o autor mergulha em cheio no ambiente das fofocas, que ele usa como um prodigioso manancial de informações sobre o cotidiano popular, desde o seu primeiro romance até o último. ${ }^{10}$ Como logo percebe Alfredo, naquele bairro da Passagem dos Inocentes, assim como em Muaná e em Cachoeira do Arari, ali "todos fossavam a vida do próximo, do mundo só viam o imundo" (INO, p. 180). O representante dessa voz geral é o bêbado Cara-Longe, que se aproxima de Alfredo quando este vai à taberna da esquina comprar uma garrafa de querosene:

“ - Vizinho do 268, meu batuta, o "Zéfiro" como vai? O "Pégaso", o Belerofonte? E essa garrafa [...]? Cana para a dona da casa [...] abrir o apetite? [...] Amanhã é quarta-feira. [...] Olhe aqui no calendário [...], marquei as quartas-feiras de cada mês. Amanhã é dia. [...] A rainha das nossas palhas [...] vai dar [...] seu giro pelo Centro. [...]. Metade das saias desta Passagem inventa o diabo desse passeio da quarta-feira." "A pérola vai sair de sua concha, amanhã. Em que outra concha se guarda por umas horas? Algum comandante? Um dentista? O hindu astrólogo do Palácio das Musas? [...] A senhora Quarta-Feira pega o circular externo e volta pelo interno. Faz o seu movimento de translação em torno de um sol que deve estar escondido num gabinete dentário, numa sala de quiromancia, num chatô de cortina [...]. Ou na igreja de Santana ao confessionário com aquele galante vigário? Ela dá assim um laço em volta da cidade. [...] O itinerário da passeante eu explico...” (INO, p. 175-176 e 178).

Depois de ouvir essas insinuações e malícias do Cara-Longe, Alfredo está preparado para escutar também os comentários de outros vizinhos a respeito do passeio de dona Celeste. Eis algumas das alfinetadas, que na nossa montagem colocamos na boca de duas fofoqueiras:

"Aquela casada ia num rumo que decente não era, só podia ser de quem deixou a alma na unha do Cão [...]."

10 Segundo Rosa Assis (2002, p. 22), "Passagem dos Inocentes é [...] entre todos os livros de Dalcídio, o que mais espelha e estampa a linguagem do homem rústico paraense em seus contextos rural e suburbano".

Novos Cadernos NAEA •v. 15 n. $2 \cdot$ p. 217-246 • dez. 2012 
"[...] risco de fazer a Nossa Senhora, de novo, derramar as suas santas lágrimas."

"O do marido lavar em sangue semelhante passeio?"

"Marido e mulher no 268 [...] não se entendiam fingindo se entenderem muito bem [...]."

"Tão bem casados pareciam que se via logo o mau casamento." (INO, p. 184).

Alfredo fica intrigado com esses comentários. Ele quer entender a situação em que vive o casal e se pergunta: "Por que o seu Antonino Emiliano nenhum tento dava ao passeio da quarta-feira? Casou com a d. Celeste depois daquela viagem no 'Trombetas' [o navio da fuga dela], por que?” (p. 188) Em nossa segunda cena desse ato mostramos como o marido de dona Celeste faz de Alfredo o seu confidente, pondo-o a par dos fatos:

“- Do sobrado [em Muaná] caímos nesta cabana, parente.” (INO, p. 108.) "O "Zéfiro" [por ser usado principalmente pelo Leônidas] é prejuízo em cima de prejuízo. Nunca chega a tempo. [...] Posso assim conseguir fretes? [...] E o nosso de-comer? Não é com os trinta mensais que a tua mãe te manda que esta casa se sustenta. Resultado: vendo os azulejos, desmancho o sobrado. Doer me dói, sim, mas que remédio. Celeste, Deus me livre, não sabe nem vai saber. A ti te digo mas [...] não ouviste. Vou fazer tudo para ela não ir em junho [a Muaná]. Nem dezembro. Passamos a comer de azulejos [...]." (INO, p. 190-191).

Alfredo presencia, portanto, como marido e mulher vão cada um para direções opostas. Enquanto ela se evade para um mundo de fantasias românticas, ele se atém às questões materiais, chegando até a vender vestidos dela no Ver-o-Peso, e pensando em partir para o garimpo, com que se consumaria a desintegração daquela família.

Vejamos agora o passeio de dona Celeste, que constitui a nossa penúltima cena. Estamos numa tarde de quarta-feira: ela sai e Alfredo lhe segue os passos, às escondidas, como um detetive (cf. INO, p. 192-201). Uma vez que esse episódio do romance constitui ao mesmo tempo uma introdução à parte central de Belém, em forma de uma cartografia sentimental, montamos paralelamente a essa cena uma aula sobre a geografia e a história dos lugares por onde ela passa. É também um meio para os nossos participantes, professores e alunos, refletirem sobre o cotidiano de suas aulas. Como "guias", mantivemos as figuras das duas fofoqueiras, transformando em diálogo as informações do narrador e do personagem-observador Alfredo sobre os deslocamentos de dona Celeste. Exemplo: 


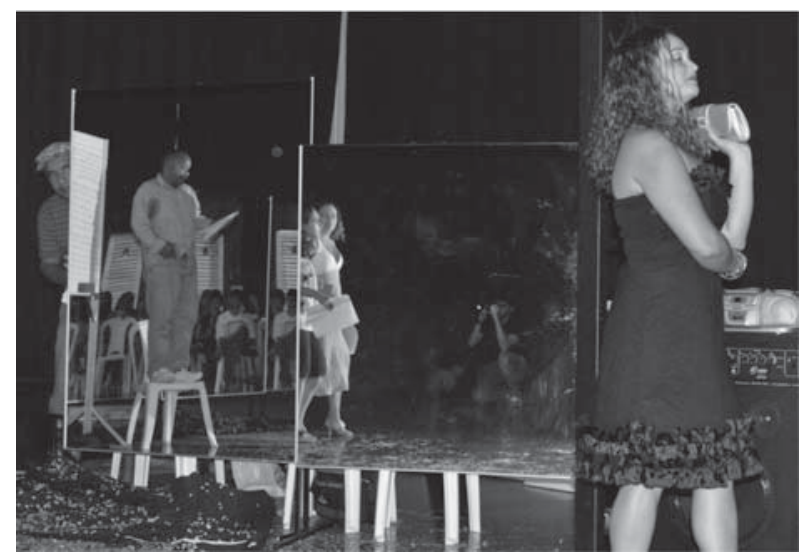

Foto 5: A aula de geografia e o passeio de dona Celeste.

[Fofoqueira 1] - "Aonde vai essa dona, meu Santo Antonio de Lisboa?” [Fofoqueira 2] - "Ela saiu pela esquina até o largo de Santa Luzia. Eu vi ela apanharobondecircular, seguindopela Generalíssimo”"(cf.INO,p.192-193).

Nesse momento, entra em cena o "Professor de Geografia", que inventamos e que explica aos alunos - e também a todos os leitores não familiarizados com a topografia de Belém - o significado de ruas, praças e bairros da cidade. Como neste exemplo:

"A Avenida Generalíssimo Deodoro recebeu este nome em homenagem ao proclamador da República e chefe do Governo provisório, na transição política que marcou o fim do Império. O Generalíssimo Manuel Deodoro da Fonseca tomou parte ativa na guerra do Paraguai [...]” (CRUZ, 1992, p. 88).

Assim acontece ao longo de todo o trajeto de dona Celeste: do Largo de Nazaré, passando pela 16 de Novembro até a Cidade Velha (cf. INO, p. 193195); de lá, pela rua Conselheiro João Alfredo, ao bairro do Reduto, onde ela desce do bonde e continua a pé (p. 195). Nessa altura, inserimos uma votação dos alunos que assistem à apresentação e preferem que o professor de Geografia interrompa a aula, para todo mundo poder se concentrar no passeio misterioso da protagonista. Depois de ela entrar pela Piedade e passear pela rua Manoel Barata, ela para nos Correios, no guichê do Posta Restante (p. 196). "Que bilhete será que ela recebeu?”, especula uma das fofoqueiras. Dona Celeste continua, descendo a rampa da rua Quinze: rumo ao Ver-o-Peso ou ao Cais? (p. 197). Isso provoca novos comentários:

[Fofoqueira 1] - "Vai embarcar outra vez no 'Trombetas'. Será que o comandante já está esperando?" 
[Fofoqueira 2] - "Não, é o rebocador 'Conqueror' - O Conquistador! Ela gosta de nome mágico."

[Fofoqueira 1] - "Mas lá sobe ela pela Padre Prudêncio. Será que ela vai se confessar com aquele galante vigário?” (cf. INO, p. 197, 199 e 178).

Assim, a cada passo da dona Celeste aumenta o mistério.

Ocorre que também neste caso, a ficção dessa mulher, e a de Alfredo, que lhe quer desvendar o segredo, é desmontada. A tentativa de uma evasão individual de um cotidiano enfadonho e degradante é sobrepujada por uma ação política coletiva. O romancista coloca o seu personagem, e também o leitor, diante de ambas as opções. É esse o tema da nossa última cena. No largo da Pólvora, ou seja, na Praça da República, o detetive amador, que se distraiu por um momento, é impedido de seguir a dama misteriosa, pois uma multidão de manifestantes se interpõe no seu caminho.

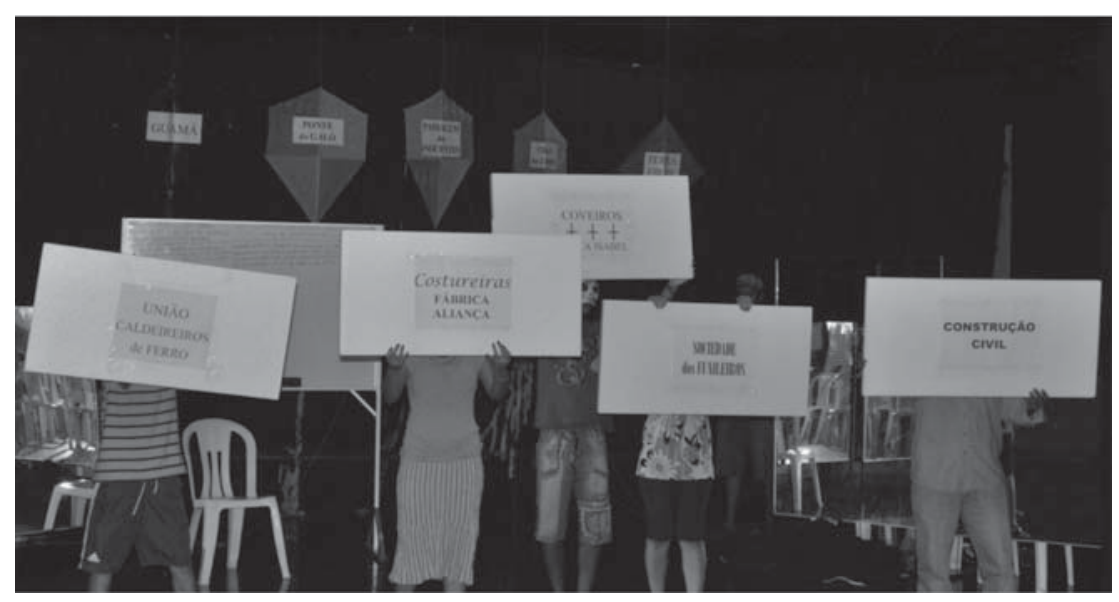

Foto 6: A manifestação popular.

Eles carregam faixas que mostram a sua organização coletiva:

$$
\begin{aligned}
& \text { "COSTUREIRAS DA FABRICA ALIANCA", "SOCIEDADE } \\
& \text { BENEFICENTE DOS FUNILEIROS", "FEDERACAOA } \\
& \text { DAS CLASSES EM CONSTRUCAAO CIVIL", "UNIAOO DOS } \\
& \text { CALDEIREIROS DE FERRO", "COVEIROS DE SANTA ISABEL" } \\
& \text { (INO, p. 202-204). }
\end{aligned}
$$

Trata-se de um protesto de operários e de suas mulheres contra o descaso dos políticos com os problemas da cidade: o acúmulo de lixo nas ruas, que traz a praga das moscas, que por sua vez causa a morte de muitas crianças: 


\begin{abstract}
“AS NOSSAS CRLANCAS ESTÃO MORRENDO. ONDE ESTÃO OS DOUTORES DESTA CIDADE?”, "CHEGA DE TANTO MORRER CRIANCAP?, "QUEREMOS PAGAMENTO", "REMOVAM O LIXO”, "SALVEM AS CRIANCAS" (INO, p. 202-204).
\end{abstract}

Em vez de atender às justas reivindicações dos manifestantes, as autoridades mandam a cavalaria investir contra eles. A fala final da nossa montagem é de uma das mulheres que pergunta, revoltada: “ - Vão curar a doença mandando carregar as armas contra as mães?” (INO, p. 213).

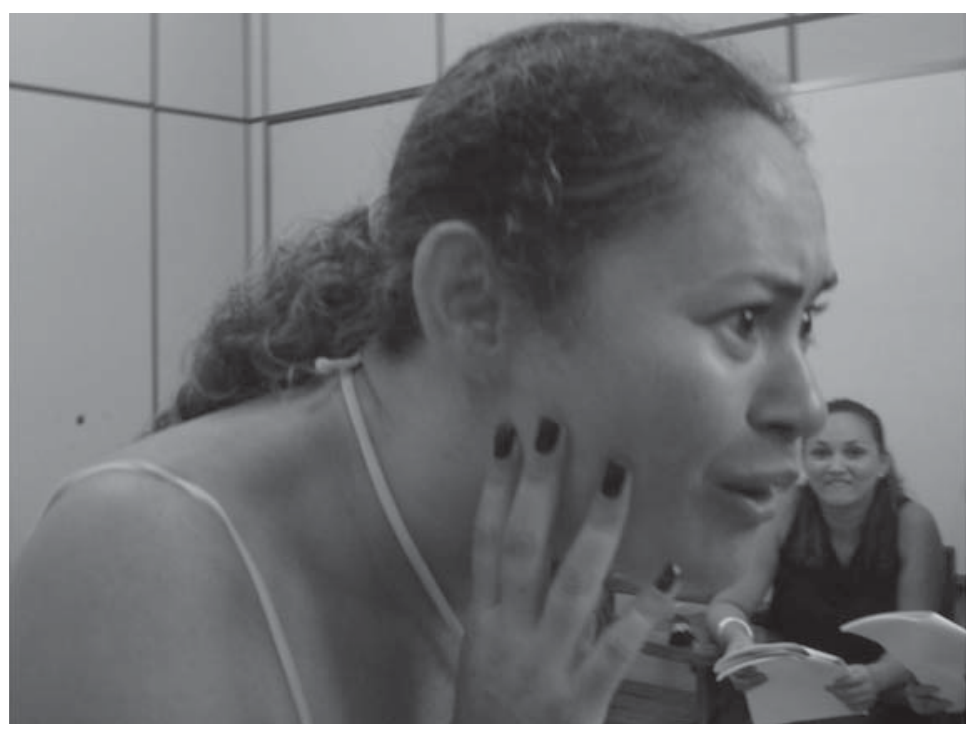

Foto 7: "Vão curar a doença mandando carregar as armas contra as mães?"

\title{
9 A IMPORTÂNCIA DE PASSAGEM DOS INOCENTES NO CONJUNTO DO CICLO DO EXTREMO NORTE
}

Neste episódio-chave do romance (“O passeio, a mosca e os anjos”), Dalcídio Jurandir revela-se como autor politicamente engajado em favor da causa pública. O que acresce a qualidade da obra, é que ele não opta pelo proselitismo, mas pela coexistência equilibrada entre o retrato de dois tipos de comportamento: por um lado, um desejo individual de evasão; por outro, a preocupação coletiva com os problemas da cidade.

Num estudo instigante, Benedito Nunes comenta o referido episódio, no qual "ao pé da estátua alegórica republicana, aglomeram-se diferentes grupos de trabalhadores, homens e mulheres, que envolvem Alfredo [...]. A narrativa continua em distintiva forma dialogada, em que se alternam Uma voz, A mulher grávida, A primeira voz, A voz de outra mulher [...]. Faixas se sucedem [...]”. Esses 
"diversos falares em tumulto", essas "faixas de protesto" e toda essa "polifonia de vozes" configuram o que o crítico chama de um "transbordamento dramático, a rigor, cênico, da ação" (NUNES, 2006, p. 250).

Foi o que experimentamos em nossa oficina de leitura dramática. A elaboração do roteiro cênico exigiu uma atenção especial para as falas dos personagens, no sentido de selecionar as mais expressivas; e o texto do romance veio ao nosso encontro, justamente com essa qualidade de "transbordamento cênico da ação". A oficina como um todo mostrou que a forma teatral, por ser essencialmente lúdica, coletiva e voltada para a socialização do conhecimento, é muito apropriada para despertar o interesse pela leitura da obra de Dalcídio Jurandir. A partir dela, é possível desenvolver a capacidade de percepção da realidade amazônica e os recursos para expressá-la.

O estudo de Benedito Nunes é de interesse exemplar também pelo fato de ele ter escolhido Passagem dos Inocentes como o livro estratégico em que Dalcídio Jurandir redimensiona o conjunto do seu Ciclo Amazônico. Pois é a partir desse romance que ocorre uma "requalificação da narrativa pela linguagem", que se manifesta na "adesão da voz de quem narra à fala dos personagens, o que leva a um grau de máxima aproximação o ato de narrar e a maneira de ver e sentir o mundo de cada um deles" (NUNES, 2006, p. 249). Ou seja, a voz do narrador individual é substituída por uma voz coletiva. A narrativa se pluraliza com a entrada em cena de um grande número de personagens, com "as múltiplas vozes em tumulto de uma multidão rebelada” (p. 250). Benedito Nunes completa a sua análise de Passagem dos Inocentes explicando como a reestruturação da narrativa repercute nos quatro romances seguintes, que todos se passam na periferia de Belém:

É como se em Primeira Manhã, Ponte do Galo, Os habitantes, Chão dos Lobos a dialogação conduzisse a narração e com a narração se confundisse como maneira de ver e de sentir o mundo dos personagens em afluência. Os personagens afluem e confluem seus falares, suas dicções (NUNES, 2006, p. 249).

Ou seja, ao redimensionar o conjunto de sua obra, a partir de Passagem dos Inocentes, Dalcídio Jurandir reforçou uma característica de sua escrita que esteve presente desde a sua estreia: o "relevo dado à fala dos personagens" (NUNES, 2006 , p. 248). Com efeito, como observamos durante o nosso trabalho com o romance, as falas dos personagens vão crescendo em importância, a ponto de se tornarem os principais componentes da ação narrada. Note-se, ainda, que esse retrato da população da periferia através de suas falas, não se dá numa perspectiva folclórica, mas como um componente fundamental de uma tentativa emancipatória. 


\section{DEBATES COM O PÚBLICO E CONTINUAÇÃO DO TRABALHO}

Durante a elaboração do roteiro cênico, os participantes já se familiarizam com as falas. Depois de um ensaio geral, apresentamos, em 6 de novembro de 2009, uma leitura dramática para os professores e alunos da Escola Dr. Celso Malcher, e alguns convidados de fora. No início de 2010 retomamos os ensaios e em 15 de abril, realizamos uma apresentação pública na Universidade da Amazônia (UNAMA); ${ }^{11}$ ela foi também tema de uma reportagem da TV Cultura. Ambas as apresentações teatrais foram seguidas por debates dos atores com o público. Na UNAMA, o diálogo se deu entre professores e estudantes universitários e, por outro lado, habitantes da periferia. Queríamos saber o que o nosso trabalho teatral significou para ambos os lados. Eis uma seleção de perguntas dos espectadores e de respostas dos participantes.

Pergunta 1: Qual foi o grau de participação dos alunos? - Resposta: Esta oficina de leitura dramática foi um trabalho conjunto de quatro alunos e seis professores. Depoimentos de alunos:

Wallace: "Foi uma ação voluntária dos alunos. Eu fiquei um pouco encabulado no começo, quando peguei o papel do narrador. Mas aceitei de bom grado, abracei essa causa. E agradeço a cada um que esteve aqui presente."

Francivaldo: "Nós alunos fizemos este trabalho por livre e espontânea vontade. Nós nunca tínhamos passado por esse tipo de experiência. Para mim está sendo muito gratificante participar, principalmente porque você vê aluno e professor trabalhar juntos no mesmo espaço. Deixou de ser aluno e professor, e era um colega de trabalho. E conseguimos alcançar juntos o nosso objetivo. Foi uma relação bem legal. Foi o que houve de mais gratificante para mim nesta experiência."

Pergunta 2: A administração da Escola apoiou essa oficina de leitura dramática? Quais foram as condições para vocês realizarem esse trabalho? Resposta do professor Waldinei:

"A direção da Escola Dr. Celso Malcher, na figura da professora Regina Guimarães, é uma pessoa muito sensível e aberta a esse tipo de evento. Desde o início até hoje, o que é um pouco complicado é arranjar tempo para a elaboração do roteiro e para os ensaios, porque somos professores. Para a gente poder participar deste evento, temos que sair da sala de

11 Os personagens e seus intérpretes: Narrador: Wallace da Silva. Alfredo: Nelson Costa Fonseca e Moisés Braga do Nascimento. Leônidas e Professor de Geografia: Waldinei do Carmo de Souza. Dona Celeste, na barraca: Anna Carolina de Abreu Coelho; ela fez também o papel da Fofoqueira 1. Dona Celeste aos 18 anos: Rosane do Socorro Pompeu de Loiola; ela interpretou também a Fofoqueira 2. Dona Celeste da $4^{a}$ feira: Rosana F. dos Passos. Belerofonte: Gilvan Fiel Capela Jr. O porco Pégaso: Ana Daniele Costa Pantoja e Francivaldo de Aviz Araújo; este fez também o papel do Cara-Longe.

Novos Cadernos NAEA • v. 15 n. 2 • p. 217-246 • dez. 2012 
aula. Aí fica um corre-corre, porque você tem um compromisso dos dois lados. A gente, então, tem que ficar costurando um pouco. Mas é também prazeroso. $\mathrm{E}$ a diretora foi sensível à nossa experiência e liberou a gente, na medida do possível. E assim a gente foi levando, até chegar neste resultado."

Pergunta 3: Qual é o objetivo principal dessa leitura dramática? É uma atividade para formar leitores? - Respostas da professora Rosane e do aluno Gilvan:

"Nós, professores da Escola Estadual Dr. Celso Malcher, temos tido
essa política de fomentar a literatura entre os nossos alunos. Então,
quando o professor Willi chegou com o projeto de estudar o Dalcídio
Jurandir, a gente abraçou, porque entendemos que a leitura tem que fazer
parte da nossa vida e temos que desenvolver essa aptidão pela leitura.
Especialmente quando se trata de um autor da Amazônia, que retrata a
nossa realidade. Dalcídio retrata fielmente o homem amazônico. É isso
que a gente tem que levar para os nossos alunos, para que eles também
se valorizem como cidadãos da Amazônia. Por isso a gente teve muito
carinho e muita satisfação em desenvolver esse projeto.”
"Foi o primeiro contato que eu tive com a obra de Dalcídio Jurandir.
Eu nunca tinha lido um livro dele. Gostei e espero ler outros livros dele
também. Ele é um autor da Amazônia que nos dá orgulho.”

Pergunta 4: Em que medida esta apresentação teatral, com cenas como a iniciação do protagonista Alfredo às condições de vida nas baixadas, estimula a reflexão sobre a periferia? - Resposta dos professores Rosane e Waldinei:

"Eu sou uma leitora assídua de Dalcídio Jurandir. Já li Chove nos campos de Cachoeira, Ribanceira e Marajó. Eu ainda não tinha lido Passagem dos Inocentes, porque a gente tem dificuldade em ter acesso ao conjunto da obra. Ele não está disponível. E Dalcídio Jurandir não é fácil para quem vai começar a ler. Eu diria até que ele é um autor difícil. Mas depois que a gente consegue, a gente vai entendendo. [...] A gente consegue visualizar em suas obras, pelo menos nessas que eu li, esse elemento muito forte da consciência crítica. Em Belém, a gente vê a população lutando pela melhoria das condições de vida na baixada, o que foi refletido aqui numa cena."

"O objetivo da nossa encenação de Dalcídio Jurandir foi fazer as pessoas refletirem sobre Belém, sobretudo sobre sua periferia. Dos anos 1920 para hoje, o que mudou? Os problemas descritos no romance continuam: lixo nas ruas, falta de saneamento, falta de saúde, exploração de crianças e adolescentes como força de trabalho. O que as autoridades fizeram?”

Pergunta 5: O episódio que mais intrigou os espectadores foi o passeio misterioso da dona Celeste. No romance há algum esclarecimento desse mistério? E por que essa personagem é interpretada por três atrizes diferentes? - Resposta: Vamos ouvir os esclarecimentos das três participantes que fazem o papel de dona Celeste: 
Rosane: "A gente tentou mostrar que a personagem tem três fases e três aspectos de sua vida. 1) A jovem de dezoito anos, em Muaná; 2) A Cecé dos devaneios; eu, enquanto leitora da obra, acredito que ela não se libertou inteiramente daquele mundo que viveu no passado, em que a família tinha um poder, na época em que ela ainda frequentava bailes. Então, ela vivencia isso, mesmo morando num barraco. 3) E a dona Cecé, a dona de casa que vive nesse barraco da periferia. Lá em Muaná, ela dá a entender para os moradores que em Belém ela vive muito bem. Ela procura manter todo o requinte, toda a vida de poder que ela tinha lá. Mas aqui em Belém, a vida dela é totalmente outra. Ela mora na baixada, com todos os seus problemas. Mas a dona Cecé não aceita essa realidade. Por isso ela vive esses devaneios, o passeio dela que vai pelo centro da cidade. Talvez, quem sabe, ela é ainda apaixonada por aquele comandante que ela deixou para trás."

Rosana: "A dona Celeste quer aquele mundo do passeio. E ela mostra que está fazendo um passeio, que ela vai com um homem tal, com aquele outro. As fofoqueiras pensam que ela faz isso. Mas na verdade, ela está vivendo um sonho, uma ilusão: de passear, de estar livre, de se libertar, de fazer o que ela tem vontade de fazer."

Anna: "Alfredo passa o tempo todo tentando descobrir o que dona Celeste vai fazer. Mas ele se perde na multidão e a gente acaba não sabendo. Se ela vai se encontrar com o comandante, de verdade. Ou se ela vai rodando por lá, como faz naquele sonho, com a mala, com os vestidos. Pode ser que ela só ande pela cidade e rememore. Tem tantas possibilidades. Cada um que lê o texto do Dalcídio, vai dar a sua interpretação. [...] A Celeste é três pessoas, como está no texto. A gente tentou passar isso. Ela se transforma, ela tem a parte dela que é a garota ainda, com todos os sonhos, tem o momento em que ela sonha e se liberta ou não se liberta. Ela vive uma grande ilusão. [...] Eu faço a Cecé pobre e a Rosane faz a Cecé naquele momento, dando aquele pulo da cama para sonhar e voltar aos dezoito anos. E a gente faz também as duas fofoqueiras. Juntas, elas são como se fosse uma cabeça de Hidra. Tem toda uma mitologia. Como na cabeça de seu Antonino Emiliano. Então, elas são uma serpente de duas cabeças, perseguindo a Celeste."

Pergunta 6: Em que consiste, na opinião de vocês, a atualidade do romance Passagem dos Inocentes? - Resposta do aluno Francivaldo:

"Vocês podem reparar que a dona Celeste passeia só pelas avenidas importantes de Belém: Generalíssimo, Avenida Nazaré... Mas, ao mesmo tempo, ela mora na baixada. Isso, de ela morar na baixada, nos dá um grande orgulho. Não só porque o romance se passa na baixada, mas também porque nós, que interpretamos esse texto, moramos lá. Somos protagonistas e falamos do nosso próprio bairro, de nossa própria realidade. Então, o passeio dela, vocês reparam que é só nas avenidas grandes. Não é porque a gente mora na baixada, que a gente não possa passear, não possa sair de lá e ir para lugares melhores. Não é porque a gente não tem uma condição de vida boa que a gente não possa sonhar como a dona Celeste sonha. Ela sonha alto. Mesmo morando na baixada, ela pode ter 
o sonho de um dia estar desfilando nessas avenidas importantes, cheia de glamour, cheia de prosperidade, toda, toda. Isso é também um ponto muito gratificante nessa parte do teatro, do Dalcídio Jurandir. É isso que vem na nossa cabeça. Que os sonhos não são só para os que têm dinheiro, os sonhos são para todos."

Dando continuidade a essa experiência bem-sucedida com Passagem dos Inocentes, trabalhamos, em 2011, numa montagem conjunta dos dois romances seguintes: Primeira Manhã e Ponte do Galo, em que o protagonista se vê na encruzilhada entre a educação formal pelo ginásio e os saberes transmitidos pela "escola da rua". Também neste caso, estamos elaborando um artigo sobre o processo de confecção do roteiro e a experiência da montagem. Respondendo ainda à pergunta de um espectador que queria saber da possibilidade de outras pessoas também participarem do trabalho que estamos desenvolvendo, informamos que numa publicação complementar pretendemos colocar os roteiros de ambas as adaptações cênicas à disposição de professores, alunos e demais interessados: como incentivo à leitura dos romances de Dalcídio Jurandir e como registro de um método pedagógico a ser aperfeiçoado e ampliado.

\section{AGRADECIMENTOS}

A Francisco Batista, que estabeleceu o contato inicial para a formação do grupo; a Regina Guimarães, diretora da escola Dr. Celso Malcher; Profa. Célia Jacob, Coordenadora do Curso de Letras da UNAMA; Prof. Francisco Cardoso, Superintendência de Pesquisa (UNAMA); Profa. Vera Soares, Coordenadora da Supex (UNAMA); Profa. Neusa Pressler (UNAMA); e Geneviève Pressler (por algumas das fotografias). Agradeço também à Adélia Bezerra de Meneses e Fátima Monteiro, pelo diálogo durante a redação deste artigo. E ao CNPq, pelo apoio a esta pesquisa.

\section{REFERÊNCIAS}

ASSIS, R. A fala 'caboca' em Passagem dos Inocentes. Belém: UNAMA, 2002.

BENJAMIN, W. Versuche über Brecht. Frankfurt: Suhrkamp, 1971.

Origem do drama barroco alemão. Tradução Sergio Paulo Rouanet. São Paulo: Brasiliense, 1984. 
CRUZ, E. Ruas de Belém: Significado histórico de suas denominações. 2. ed. Belém: CEJUP, 1992.

DALALIO, M. F. Da violência ao diálogo: Teoria e práxis de uma oficina teatral baseada em Grande Sertão: Veredas". 2011. Dissertação (Mestrado). Universidade de São Paulo, FFLCH, São Paulo, 2011.

DAVIS, M. Planeta Favela. Tradução Beatriz Medina. São Paulo: Boitempo, 2006.

FREUD, S. Über Deckerinnerungen [Sobre lembranças encobridoras]. In: Gesammelte Werke I. Frankfurt: S. Fischer, 1948. p. 531-554.

FURTADO, M. T. Universo derruído e corrosão do herói em Dalcídio Jurandir. Campinas: Mercado de Letras, 2010.

HOMERO. Ilíada. Tradução Haroldo de Campos. 4. ed. São Paulo: Arx, 2003.

JURANDIR, D. (1941). Chove nos campos de Cachoeira. 7. ed. Rio de Janeiro: 7 Letras, 2011.

Barbosa, 2008.

(1947). Marajó. 4. ed. Belém: EdUFPA; Rio de Janeiro: Casa de Rui _ (1958). Três casas e um rio. 3. ed. Belém: CEJUP, 1994.

(1960). Belém do Grão-Pará. 2. ed. Belém: EdUFPA; Rio de Janeiro: Casa de Rui Barbosa, 2004

(1963). Passagem dos Inocentes. 2. ed. Belém: Falangola, 1984.

(1967). Primeira manhã. 2. ed. Belém: EdUEPA, 2009.

Ponte do Galo. São Paulo: Martins; Rio de Janeiro: INL, 1971.

Os habitantes. Rio de Janeiro: Artenova, 1976.

Chão dos Lobos. Rio de Janeiro: Record, 1976. 291 p.

Ribanceira. Rio de Janeiro: Record, 1978.

NUNES, B. Dalcídio Jurandir: as oscilações de um ciclo romanesco. In: NUNES, B.; PEREIRA, R.; PEREIRA, S. R. (Orgs.). Dalcídio Jurandir: romancista da Amazônia. Belém: SECULT; Rio de Janeiro: Casa de Rui Barbosa, 2006, p. 245-251.

PENTEADO, A. R. Belém - Estudo de geografia urbana. Belém: EdUFPA, 1968. 2. v.

VALENTE, J. A História nas ruas de Belém: Umarizal. Belém: CEJUP, 1993. v. 2 